\title{
Diversity-Oriented Synthesis of $\beta$-Lactams and $\gamma$-Lactams by Post-Ugi Nucleophilic Cyclization: Lewis Acids as Regioselective Switch
}

\author{
Zhenghua Li, ${ }^{[a]}$ Upendra Kumar Sharma, ${ }^{[a]}$ Zhen Liu, ${ }^{[b]}$ Nandini Sharma, ${ }^{[a]}$ \\ Jeremy N. Harvey, ${ }^{[b]}$ and Erik V. Van der Eycken*[a]
}

Keywords: Multicomponent reactions / Nucleophilic cyclization / Regioselectivity / Lewis acids / Lactams

Heterocyclic fused $\alpha$-methylene $\beta$-lactams were successfully synthesized by a post-Ugi $\mathrm{In}^{\mathrm{III}}$-catalyzed intramolecular addition reaction. Switching from $\mathrm{InCl}_{3}$ to $\mathrm{AlCl}_{3}$ led to the regioselective synthesis of $\alpha, \beta$-unsaturated $\gamma$-lactams. More- over, replacing terminal alkynes by substituted alkynes in the Ugi adducts resulted in the exclusive formation of $\gamma$-lactams with both catalytic systems.

\section{Introduction}

2-Azetidinones, commonly known as $\beta$-lactams, are wellestablished privileged scaffolds as proven by their widespread applications in medicinal chemistry. ${ }^{[1]}$ The core structure of commonly used antibiotics such as penicillin, aztreonam, nocardicin $\mathrm{A}$, and the cholesterol lowering drug ezetimibe is the $\beta$-lactam ring (Figure 1). ${ }^{[1,2]}$ In addition, $\beta$ lactams also serve as versatile building blocks for the synthesis of various nitrogen-containing compounds such as vitamins, alkaloids, and $\beta$-amino acids. ${ }^{[3]}$ The classical route for the construction of the $\beta$-lactam core is the Staudinger reaction through the $[2+2]$ cycloaddition of imines to ketenes. ${ }^{[4]}$ The generation of the latter requires treatment of activated carboxylic acid derivatives such as acyl chlorides, which sometimes lowers the synthetic utility. Considering the vast pharmacological significance of the $\beta$-lactam framework and the growing concern regarding bacterial resistance, the development of new methodologies towards the diversification of existing $\beta$-lactam antibiotics seems to be imperative. ${ }^{[5]}$ As a result, several new synthetic approaches have been developed, ${ }^{[6]}$ with particular emphasis on the generation of $\alpha$-methylene $\beta$-lactams, ${ }^{[7]}$ which are versatile compounds delivering building blocks for the construction of various $\beta$-lactam antibiotics ${ }^{[7 \mathrm{c}]}$ (Scheme 1).

[a] Laboratory for Organic \& Microwave-Assisted Chemistry (LOMAC), Department of Chemistry, University of Leuven (KU Leuven),

Celestijnenlaan 200F, 3001 Leuven, Belgium E-mail: erik.vandereycken@chem.kuleuven.be http://chem.kuleuven.be/organ/lomac/

[b] Quantum Chemistry and Physical Chemistry Section, Department of Chemistry, University of Leuven (KU Leuven), Celestijnenlaan 200F - box 2404, Leuven, Belgium

$\square$ Supporting information for this article is available on the WWW under http://dx.doi.org/10.1002/ejoc.201500270.

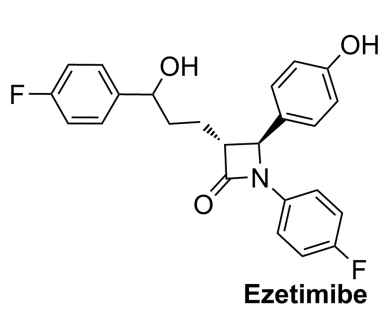<smiles>C[C@H]1[C@@H](NC(=O)C(=NC(=O)C(=O)OC(C)(C)C)c2csc(N)n2)C(=O)N1S(=O)(=O)O</smiles><smiles>[R]C(=O)N[C@H]1C(=O)N2[C@@H](C(=O)O)C(C)(C)S[C@H]12</smiles>

Figure 1. Examples of $\beta$-lactam-core-containing pharmaceuticals.

Over the last few decades, multicomponent reactions $(\mathrm{MCR})^{[8]}$ and transition-metal-catalyzed ${ }^{[9]}$ post-MCR transformations have enabled easy access to complex heterocyclic scaffolds in a few steps. ${ }^{[10]}$ Strategies for generating $\beta$-lactams by employing $\beta$-amino acids ${ }^{[11]}$ or $\beta$-keto acids ${ }^{[12]}$ as functionalized substrates in the Ugi reaction have also been developed. Recently, bromoacetic acid ${ }^{[13]}$ and phenylpropiolic acid ${ }^{[14]}$ have been used to synthesize functionalized $\beta$-lactams involving a sequential base-catalyzed tandem Ugi reaction and intramolecular cyclization. Nonetheless, newer methodologies in terms of increased substrate scope as well as starting material availability are always welcome. In continuation of our attempts towards the development of diversity-oriented syntheses of various heterocyclic scaffolds through post-Ugi transformations, ${ }^{[15]}$ we envisioned the synthesis of heterocyclic fused $\alpha$-methylene $\beta$ lactams by combination of a MCR with a metal-catalyzed cascade cyclization. Herein, we report post-Ugi In ${ }^{\mathrm{III}}$-catalyzed intramolecular nucleophilic cyclization for the synthe- 
Reported work:

(i) Saha-Möller and coworkers, 2000<smiles>[R]C(O)C(=C)C(=O)OC1CC1CC(C)C(C)C([R])OC</smiles>

(ii) Bsak and coworkers, 2004

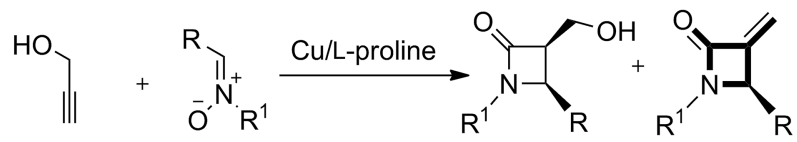

(iii) Ding and coworkers, 2012

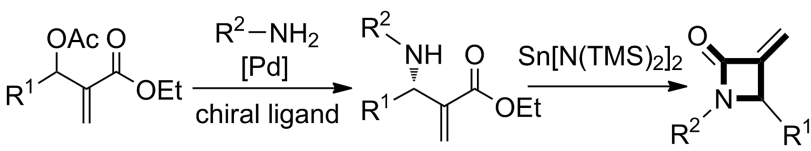

(iv) Lei and coworkers, 2014
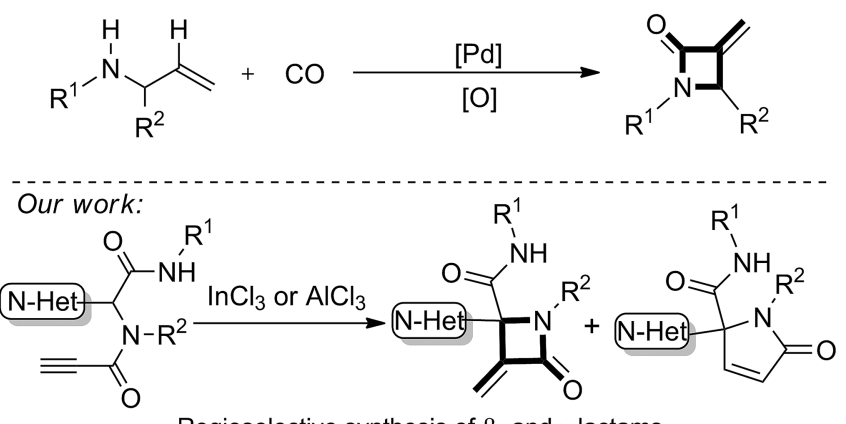

Regioselective synthesis of $\beta$ - and $\gamma$-lactams

Scheme 1. Synthetic methods for $\alpha$-methylene $\beta$-lactams; PMB $=$ p-methoxybenzyl, Ms = methylsulfonyl.

sis of $\mathrm{N}$-heterocyclic fused $\alpha$-methylene $\beta$-lactams. Interestingly, switching from $\mathrm{In}^{\mathrm{III}}$ to $\mathrm{Al}^{\mathrm{III}}$ resulted in the generation of another important class of N-heterocycles, that is, unsaturated $\gamma$-lactams, starting from the same Ugi adduct (Scheme 1).

\section{Results and Discussion}

Initially, the Ugi four-component reaction (4-CR) $)^{[16]}$ of imidazo[1,2-a]pyridine-2-carbaldehyde (1a), p-methoxybenzylamine (2a), propiolic acid (3a), and cyclohexyl isocyanide (4a) in methanol at room temperature generated adduct 5a in $84 \%$ yield, which was selected to optimize the reaction conditions of the next step. In continuation of our previous success with gold and silver catalysis for the activation of alkynes, ${ }^{[14]}$ we began our studies by screening these catalysts in 1,2-dichloroethane (DCE) at $120^{\circ} \mathrm{C}$ for $12 \mathrm{~h}$ (Table 1, entries 1-3). However, none of the catalysts was able to complete the reaction. Moreover, the selectivity for desired $\alpha$-methylene $\beta$-lactam 6 a was not good. Therefore, we turned our attention to $\mathrm{In}^{\mathrm{III}}$ catalysts, as these have recently emerged as dual activators for carbonyl compounds as well as for terminal alkynes in various reactions. ${ }^{[17]}$ Delightedly, the application of $10 \mathrm{~mol}-\%$ of $\mathrm{InCl}_{3}$ was able to complete the reaction, and desired exo-cyclized $\alpha$-methylene $\beta$-lactam 6 a was isolated in $36 \%$ yield (Table 1 , entry 4). Increasing the catalyst loading of $\mathrm{InCl}_{3}$ to $20 \mathrm{~mol}-$ $\%$ led to isolation of $\mathbf{6 a}$ in $73 \%$ yield (Table 1 , entry 5). However, a further increase in the catalyst loading to 30 mol- $\%$ did not significantly enhance the outcome of the reaction (Table 1, entry 6). A drastic reduction in yield and selectivity was observed upon switching the catalyst to indium(III) trifluoromethanesulfonate [In(OTf) 3 ; Table 1, entry 7]. Changing the solvent to toluene gave a slightly improved yield of $\mathbf{6 a}$ (Table 1, entry 8), whereas $o$-xylene and $\mathrm{MeCN}$ produced reduced yields (Table 1, entries 9 and 10). Increasing the catalyst loading to $30 \mathrm{~mol}-\%$ in toluene delivered $\mathbf{6 a}$ in $88 \%$ yield (Table 1, entry 11). No further improvement in yield or selectivity was observed upon further increasing the amount of catalyst (Table 1, entry 12) or reducing the reaction time or temperature (Table 1, entries 13 and 14). We next attempted to develop a catalytic system for the exclusive generation of endo-cyclized product, that is, $\gamma$-lactam 7a, which was observed as a minor product in almost every case. Interestingly, replacing $\mathrm{InCl}_{3}$ with the readily available Lewis acids $\mathrm{AlCl}_{3}$ and $\mathrm{ZnCl}_{2}$ resulted in the formation of $\gamma$-lactam $7 \mathbf{a}$ in yields of 75 and $61 \%$, respectively (Table 1, entries 15 and 16). However, with $\mathrm{CuI}$ and $\mathrm{K}_{2} \mathrm{CO}_{3}$ only decomposition of Ugi adduct 5a was observed (Table 1, entries 17 and 18).

Table 1. Optimization of the intramolecular addition. ${ }^{[a]}$

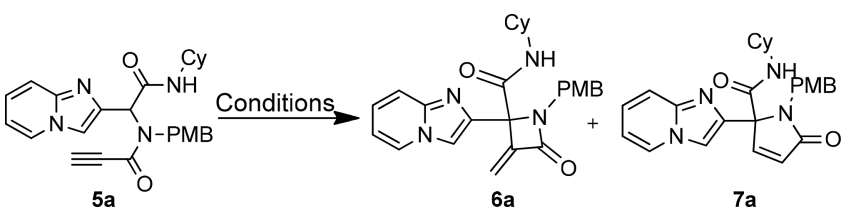

\begin{tabular}{|c|c|c|c|c|c|}
\hline Entry & $\begin{array}{l}\text { Catalyst } \\
(\mathrm{mol}-\%)\end{array}$ & Solvent & $\begin{array}{l}\text { Time } \\
{[\mathrm{h}]}\end{array}$ & $\begin{array}{l}\text { Temp. } \\
{\left[{ }^{\circ} \mathrm{C}\right]}\end{array}$ & $\begin{array}{l}\text { Conversion }[\%]^{[b]} \\
(\mathbf{6 a} / 7 \mathbf{a})\end{array}$ \\
\hline 1 & AgOTf (10) & DCE & 12 & 120 & $90(40: 50)$ \\
\hline 2 & $\mathrm{AgSbF}_{6}(10)$ & DCE & 12 & 120 & $78(50: 28)$ \\
\hline 3 & $\mathrm{AuCl}(10)$ & DCE & 12 & 120 & $80(35: 45)$ \\
\hline 4 & $\mathrm{InCl}_{3}(10)$ & DCE & 12 & 120 & $100(36: 18)^{[\mathrm{c}]}$ \\
\hline 5 & $\mathrm{InCl}_{3}(20)$ & DCE & 12 & 120 & $100(73: 8)^{[\mathrm{c}]}$ \\
\hline 6 & $\mathrm{InCl}_{3}(30)$ & DCE & 12 & 120 & $100(74: 6)^{[c]}$ \\
\hline 7 & $\mathrm{In}(\mathrm{OTf})_{3}(20)$ & DCE & 12 & 120 & $100(40: 10)^{[\mathrm{c}]}$ \\
\hline 8 & $\mathrm{InCl}_{3}(20)$ & toluene & 12 & 120 & $100(78: 8)^{[\mathrm{c}]}$ \\
\hline 9 & $\mathrm{InCl}_{3}(20)$ & $o$-xylene & 12 & 120 & $100(68: 12)^{[\mathrm{c}]}$ \\
\hline 10 & $\mathrm{InCl}_{3}(20)$ & $\mathrm{MeCN}$ & 12 & 120 & $100(72: 28)$ \\
\hline 11 & $\mathrm{InCl}_{3}(30)$ & toluene & 12 & 120 & $100(88: 4)^{[\mathrm{c}]}$ \\
\hline 12 & $\mathrm{InCl}_{3}(40)$ & toluene & 12 & 120 & $100(86: 5)^{[\mathrm{c}]}$ \\
\hline 13 & $\mathrm{InCl}_{3}(30)$ & toluene & 6 & 120 & $100(64: 5)^{[c]}$ \\
\hline 14 & $\mathrm{InCl}_{3}(30)$ & toluene & 12 & 100 & $100(56: 5)^{[\mathrm{c}]}$ \\
\hline 15 & $\mathrm{AlCl}_{3}(10)$ & DCE & 12 & 120 & $100(0: 75)^{[\mathrm{c}]}$ \\
\hline 16 & $\mathrm{ZnCl}_{2}(10)$ & DCE & 12 & 120 & $100(13: 61)^{[\mathrm{c}]}$ \\
\hline 17 & CuI (10) & DCE & 12 & 120 & n.d. ${ }^{[\mathrm{d}]}$ \\
\hline 18 & $\mathrm{~K}_{2} \mathrm{CO}_{3}[\mathrm{e}]$ & DCE & 12 & 120 & n.d. ${ }^{[\mathrm{d}]}$ \\
\hline
\end{tabular}

[a] All reactions were run on a $0.1 \mathrm{mmol}$ scale of $\mathbf{5 a}$ in the indicated solvent $(2 \mathrm{~mL}) . \mathrm{Cy}=$ cyclohexyl. [b] Conversion and ratio based on analysis by ${ }^{1} \mathrm{H}$ NMR spectroscopy. [c] Yield of isolated product. [d] n.d.: not detected. [e] $\mathrm{K}_{2} \mathrm{CO}_{3}$ : 1 equiv.

With the optimized conditions for the synthesis of $\beta$-lactams in hand (Table 1, entry 11), we evaluated the scope and limitations of this intramolecular addition by using a vari- 
ety of different Ugi adducts 5a-t (Table 2). The intramolecular cyclization proceeded smoothly in most cases to give $\alpha$-methylene $\beta$-lactams $\mathbf{6 a}-\mathbf{t}$ in moderate to good yields. A variety of substituents in the Ugi adducts were well tolerated. Employing the standard conditions to Ugi adducts 5n/ $\mathbf{5 o}$ and $\mathbf{5 p} / \mathbf{5 q}$ prepared from 1-trityl- $1 H$-imidazole-4-carbaldehyde and 4-methylthiazole-2-carbaldehyde, respectively, produced corresponding alkylidene- $\beta$-lactams $6 \mathbf{6 n} / \mathbf{6 0}$ and $\mathbf{6 p} /$ 6q in yields of $30 / 33$ and 58/62\%, respectively. However, in the case of Ugi adduct $\mathbf{5 r}$ derived from imidazo[1,2- $a$ ]pyridine-3-carbaldehyde, no conversion was observed. Similarly, the failure of Ugi adduct $\mathbf{5 s}$ derived from benzaldehyde to form $\mathbf{6 s}$ manifests the necessity of employing a ni-

Table 2. Scope and limitations for $\beta$-lactam formation. ${ }^{[a]}$

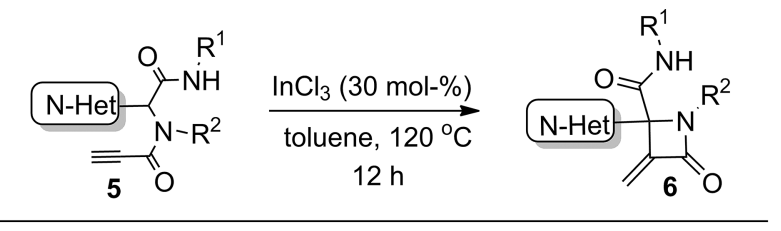

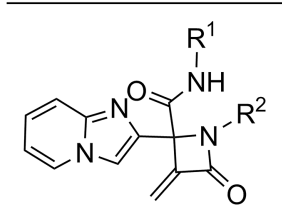

6b: $R^{1}=t B u ; R^{2}=$ piperonyl; $78 \%$

6c: $R^{1}=t B u ; R^{2}=p$-xylyl; $51 \%$

6d: $R^{1}=C y ; R^{2}=3,4-D M B ; 77 \%$

6e: $\mathrm{R}^{1}=n \mathrm{Bu} ; \mathrm{R}^{2}=p$-xylyl; $64 \%$

6f: $\mathrm{R}^{1}=t \mathrm{Bu} ; \mathrm{R}^{2}=$ benzyl; $62 \%$

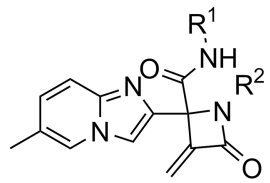

6i: $R^{1}=t B u ; R^{2}=3,4-D M B ; 72 \%$

6j: $R^{1}=$ Cy; $R^{2}=$ PMB; $58 \%$

6k: $\mathrm{R}^{1}=n \mathrm{Bu} ; \mathrm{R}^{2}=p$-xylyl; $57 \%$

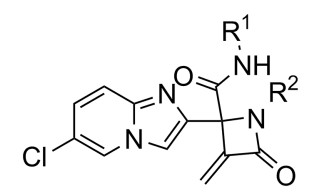

$$
\begin{aligned}
6 g: R^{1} & =t B u ; \\
R^{2} & =3,4-D M B ; 82 \%
\end{aligned}
$$$$
\text { 6h: } \mathrm{R}^{1}=\mathrm{Cy} ; \mathrm{R}^{2}=\mathrm{PMB} ; 69 \%
$$

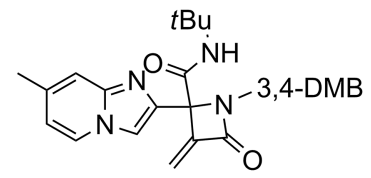

$6 \mathrm{~m}, 80 \%$

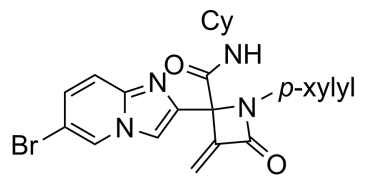

6I, $61 \%$

$\mathrm{R}^{1}$<smiles>[R]NC(=O)C1(c2cn(C)cn2)C(=C)C(=O)N1[R]</smiles><smiles>[R]NC(=O)C1(c2nc(C)cs2)C(=C)C(=O)N1[R]</smiles>

$6 n: R^{1}=C y ; R^{2}=p-x y l y l ; 30 \%$

$60: R^{1}=t B u ; R^{2}=P M B ; 33 \%$

$6 \mathbf{p}: \mathrm{R}^{1}=t \mathrm{Bu} ; \mathrm{R}^{2}=\mathrm{PMB} ; 58 \%$

$6 q: R^{1}=C y ; R^{2}=3,4-D M B ; 62 \%$

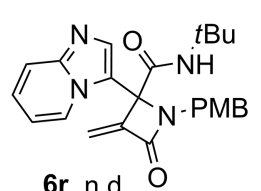

$6 r$, n.d. O

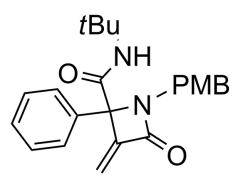

6s, n.d.

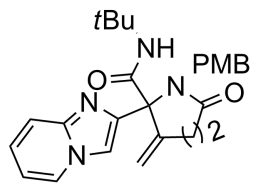

$6 t$, n.d. [a] All reactions were run on a $0.3 \mathrm{mmol}$ scale of $\mathbf{5}$ with $\mathrm{InCl}_{3}$ $(30 \mathrm{~mol}-\%)$ in toluene $(2 \mathrm{~mL})$ in a screw-capped vial at $120{ }^{\circ} \mathrm{C}$ for 12 h. 3,4-DMB = 3,4-dimethoxybenzyl. trogen-containing aromatic aldehyde in the Ugi reaction. Moreover, it was necessary to ensure that the use of propiolic acid resulted in intramolecular anti-Michael addition, as Ugi adduct 5r from 4-pentynoic acid failed to produce the desired alkylidene- $\beta$-lactam.

Further, the applicability of this protocol for the preparation of $\gamma$-lactams from Ugi adducts (e.g., 5d, 5g, 5i, 5l, 5m, and 5o) is shown in Table 3. Good to moderate yields were obtained for Ugi adducts obtained from various substituted imidazo[1,2-a]pyridine-2-carbaldehydes (e.g., 7d, 7g, 7i, 7l, and $7 \mathbf{m}$ ). However, a low yield was noticed for the Ugi adduct derived from 1-trityl-1H-imidazole-4-carbaldehyde (i.e., 7o, Table 3). In addition, to scrutinize the necessity of propiolic acid, Ugi adduct 8a was prepared from imidazo[1,2- $a$ ]pyridine-2-carbaldehyde by replacing propiolic acid with 2-butynoic acid (3c), and it was subjected to the

Table 3. Scope and limitations for $\gamma$-lactam formation. ${ }^{[a]}$

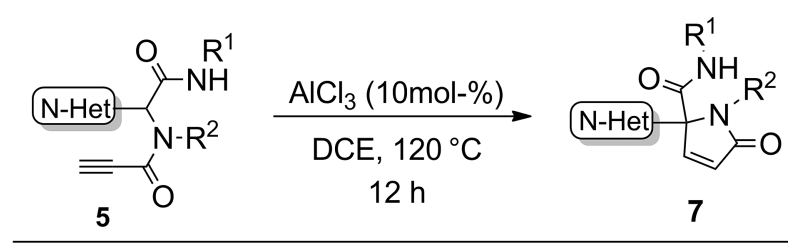

7d: $\mathrm{R}^{1}=t \mathrm{Bu} ; \mathrm{R}^{2}=3,4-\mathrm{DMB} ; \mathrm{R}^{3}=\mathrm{H} ; 63 \%$
7g: $\mathrm{R}^{1}=t \mathrm{Bu} ; \mathrm{R}^{2}=3,4-\mathrm{DMB} ; \mathrm{R}^{3}=\mathrm{Cl} ; 60 \%$

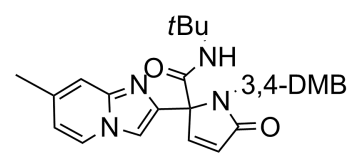

$7 \mathrm{~m}, 35 \%$

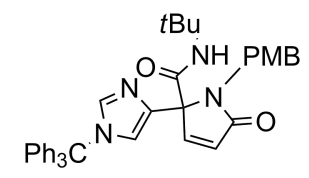

$70,20 \%$ [a] All reactions were run on a $0.3 \mathrm{mmol}$ scale of $\mathbf{5}$ with $\mathrm{AlCl}_{3}$ $(10 \mathrm{~mol}-\%)$ in DCE $(2 \mathrm{~mL})$ in a screw-capped vial at $120^{\circ} \mathrm{C}$ for $12 \mathrm{~h}$.

Table 4. Scope and limitations for $\gamma$-lactam formation from substituted propargylamides. ${ }^{[a]}$

$\begin{array}{lllllc} & & & \\ \end{array}$

[a] All reactions were run on a $0.3 \mathrm{mmol}$ scale of $\mathbf{8}$ with $\mathrm{InCl}_{3}$ $(10 \mathrm{~mol}-\%)$ in DCE $(2 \mathrm{~mL})$ in a screw capped vial at $120^{\circ} \mathrm{C}$ for $12 \mathrm{~h}$. [b] $\mathrm{AlCl}_{3}(10 \mathrm{~mol}-\%)$ was used. 


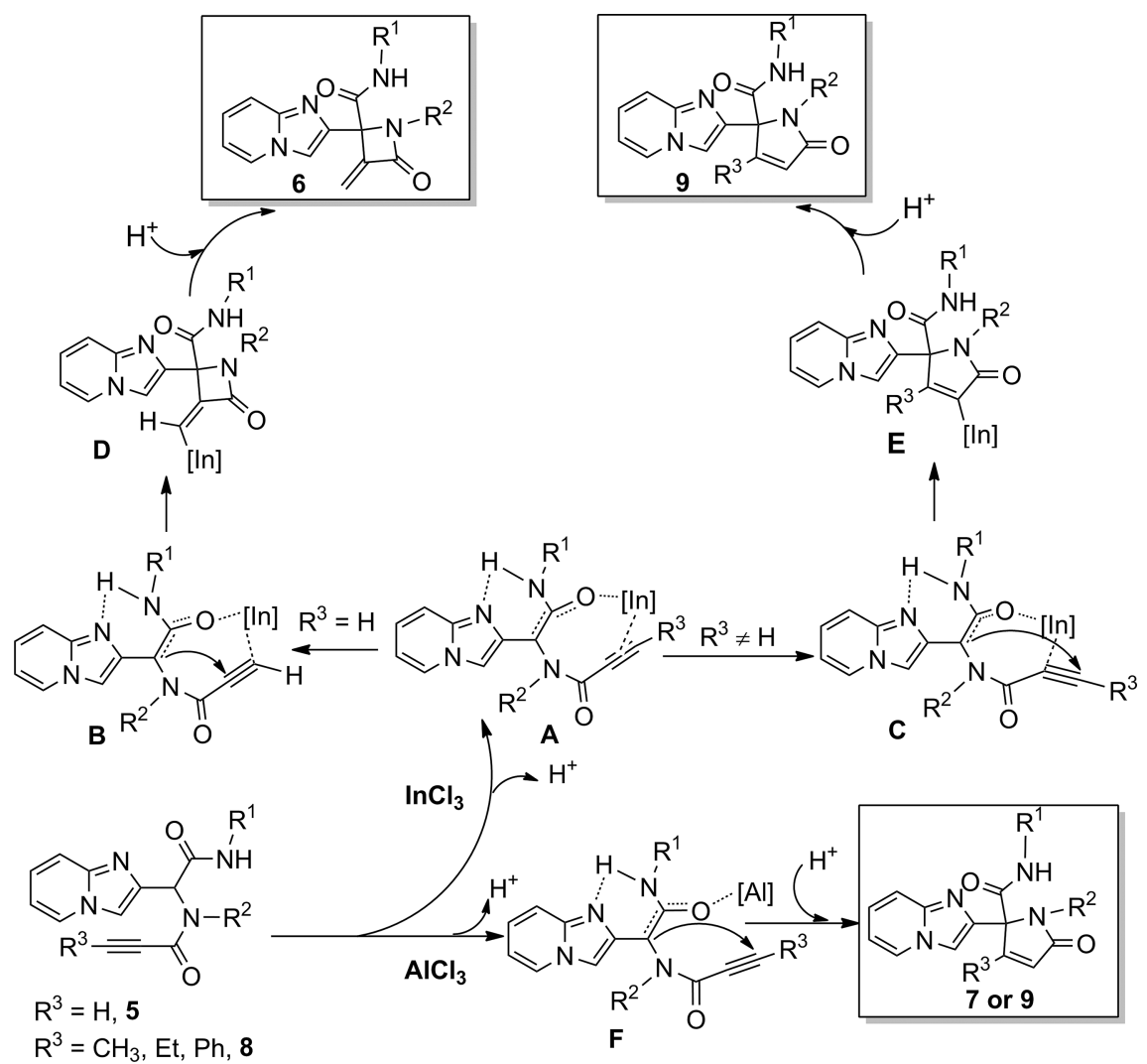

Scheme 2. Plausible reaction mechanism.

optimized conditions. However, instead of expected $\alpha$-methylene $\beta$-lactam, $\gamma$-lactam 9a was observed as the only product resulting from Michael addition (Table 4, entry 1). After checking the influence of solvents, catalysts, and so on (see the Supporting Information), the optimal conditions for this Michael addition process were found to be $120^{\circ} \mathrm{C}$ for $12 \mathrm{~h}$ in DCE as the solvent with $\mathrm{InCl}_{3}(10 \mathrm{~mol}-\%)$ as the catalyst. It is notable that employment of $\mathrm{AlCl}_{3}(10 \mathrm{~mol}-\%)$ gave $\gamma$-lactam 9a in $69 \%$ yield. The optimal process was applied successfully to diversely substituted Ugi adducts $\mathbf{8 b}-\mathbf{f}$ (see the Supporting Information) to deliver $\gamma$-lactams 9b-f in good to excellent yields. Remarkably, upon employing a bulky substituent such as a phenyl group on the alkyne, no steric hindrance was observed, and compounds 9e and $9 f$ were formed in yields of 76 and $82 \%$, respectively.

On the basis of these observations and previous reports on In ${ }^{\mathrm{III}},{ }^{[17]}$ we postulate a plausible mechanism for the nucleophilic 4-exo-dig and 5-endo-dig additions (Scheme 2). Moreover, preliminary DFT calculations were also performed to understand the reaction mechanism and selectivity with the different substrates and Lewis acids (for details, see the Supporting Information). In an initial step, we assume that the Lewis acid coordinates to the substrate, which thereby generates the enolate by deprotonation. Loss of a chloride ion from the Lewis acid leads to neutral enolate A, in which the alkyne group is coordinated to the metal center. Transition states for 4-exo-dig and 5-endo-dig ring closure have been located for $\mathrm{R}^{3}=\mathrm{H}$ and $\mathrm{Me}$, and for $\mathrm{M}=$ $\mathrm{Al}$ and In, all of which lie 8-21 $\mathrm{kcal} \mathrm{mol}^{-1}$ above the enolate.
Considering the likely computational errors, the relative energies of these transition states are in good agreement with experimentally observed ring-closure selectivities: the formation of the four-membered ring is predicted to be more favorable in the case of $\mathrm{R}^{3}=\mathrm{H}$ and $\mathrm{M}=\operatorname{In}\left(\Delta \Delta E^{t}=\right.$ $3.4 \mathrm{kcal} \mathrm{mol}^{-1}$ ), whereas the barriers for five-membered ring formation are lower in all other cases (e.g., $\Delta \Delta E^{*}=$ $-7.5 \mathrm{kcal} \mathrm{mol}^{-1}$ in the case of $\mathrm{R}^{3}=\mathrm{H}, \mathrm{M}=\mathrm{In}$ ). The products of these steps are vinyl-metal species that should undergo facile protonolysis of the C-M bonds. Partial atomic charge calculations (see the Supporting Information) suggest that the relative electrophilicity of the two acetylenic carbon atoms and thereby the selectivity is tuned by the $\mathrm{R}^{3}$ substituent and coordination to the metal.

\section{Conclusions}

In summary, we elaborated a diversity-oriented post-Ugi intramolecular approach for the synthesis of $\alpha$-methylene $\beta$-lactams and $\alpha, \beta$-unsaturated $\gamma$-lactams by employing Ugi adducts with terminal and substituted alkynes. The diversity of the desired products is guaranteed by the first step, the Ugi 4-component reaction. The operational simplicity together with the synthetic efficiency of the protocol will facilitate the development of new antibiotics for countering bacterial resistance. The biological activity of the generated compounds is under current investigation. 


\section{Experimental Section}

General Procedure for the Synthesis of Ugi Products 5 and 8: $\mathrm{Na}_{2} \mathrm{SO}_{4}(0.3 \mathrm{~g})$, amine 2 (1.2 equiv.), acid 3 (1.2 equiv.), and isocyanide 4 (1.2 equiv.) were added successively to a solution of carbaldehyde 1 (200 mg, 1 equiv.) in methanol (3 mL) in a screw-capped vial equipped with a magnetic stir bar. The mixture was stirred at room temperature for $24-48$ in the closed vial. Upon completion of the reaction, the mixture was diluted with EtOAc $(100 \mathrm{~mL})$ and was extracted with water $(50 \mathrm{~mL})$. The organic layer was washed with brine $(50 \mathrm{~mL})$, dried with magnesium sulfate, and evaporated under reduced pressure to obtain a residue, which was subjected to column chromatography (silica gel, $1-5 \% \mathrm{MeOH}$ in $\mathrm{CH}_{2} \mathrm{Cl}_{2}$ ) to afford desired product $\mathbf{5}$ and $\mathbf{8}$ as a solid. Ugi products appear as a mixture of two rotamers, so the ${ }^{1} \mathrm{H}$ NMR and ${ }^{13} \mathrm{C}$ NMR spectra are not very characteristic.

General Procedure for the Synthesis of Alkylidene $\beta$-Lactams 6 thorough $\mathrm{InCl}_{3}$-Catalyzed anti-Michael Addition: A glass vial was charged with $\mathrm{InCl}_{3}(30 \mathrm{~mol}-\%)$ and dry toluene $(2 \mathrm{~mL})$. Ugi product $5(0.3 \mathrm{mmol})$ was added. The mixture was stirred at $120^{\circ} \mathrm{C}$ until completion of the reaction. Upon completion, the mixture was purified by column chromatography (silica gel, 1-3\% $\mathrm{MeOH}$ in $\mathrm{CH}_{2} \mathrm{Cl}_{2}$ ) to afford compound $\mathbf{6}$.

General Procedure for the Synthesis of $\gamma$-Lactams 7 thorough $\mathrm{AlCl}_{3}$ Catalyzed Michael Addition: A glass vial was charged with $\mathrm{AlCl}_{3}$ $(10 \mathrm{~mol}-\%)$ and dry DCE $(2 \mathrm{~mL})$. Ugi product $5(0.3 \mathrm{mmol})$ was added. The mixture was stirred at $120^{\circ} \mathrm{C}$ until completion of the reaction. Upon completion, the mixture was purified by column chromatography (silica gel, $1-3 \% \mathrm{MeOH}$ in $\mathrm{CH}_{2} \mathrm{Cl}_{2}$ ) to afford compound 7.

General Procedure for the Synthesis of $\gamma$-Lactams 9 thorough $\mathrm{InCl}_{3}$ Catalyzed Michael Addition: A glass vial was charged with $\mathrm{InCl}_{3}$ $(10 \mathrm{~mol}-\%)$ and dry DCE $(2 \mathrm{~mL})$. Ugi product $8(0.3 \mathrm{mmol})$ was added. The mixture was stirred at $120^{\circ} \mathrm{C}$ until completion of the reaction. Upon completion, the mixture was purified by column chromatography (silica gel, $1-3 \% \mathrm{MeOH}$ in $\mathrm{CH}_{2} \mathrm{Cl}_{2}$ ) to afford compound 9.

The products were characterized by ${ }^{1} \mathrm{H}$ NMR and ${ }^{13} \mathrm{C}$ NMR spectroscopy and HRMS, and the data were all in good agreement with the assigned structures (for detailed experimental procedures and data, see the Supporting Information).

General Procedure for DFT Calculations: Briefly, DFT calculations were performed by using the B3LYP functional, the SVPP basis set for all atoms other than In, and the SDD core potential and associated basis set for In in the Gaussian 09 program package. ${ }^{[18]} \mathrm{Re}-$ ported energies include corrections for zero-point energy and dispersion [-D3(BJ) correction]. Full details of the computational protocol and additional results are in the Supporting Information.

\section{Acknowledgments}

The authors wish to thank the Belgian Fund for Scientific Research-Flanders (FWO) and the Research Fund of the University of Leuven (KU Leuven) for financial support. Z. L. is grateful to the China Scholarship Council (CSC) for providing a doctoral fellowship. N. S. and U. K. S. are grateful to the University of Leuven for $\mathrm{F}^{+}$postdoctoral fellowships. The authors also acknowledge Ir. Bert Damarsin (for HRMS).

[1] a) A. R. Katritzky, C. W. Rees, E. F. V. Scriven (Eds.), Comprehensive Heterocyclic Chemistry II, Pergamon, New York, 1996, chapter $1.18-1.20$; b) M. I. Page (Ed.), The Chemistry of $\beta$ Lactams, Blackie Academic \& Professional, New York, 1992; c) R. B. Morin, M. Gorman (Eds.), Chemistry and Biology of $\beta$ Lactam Antibiotics, vol. 1-3, Academic Press, New York, 1982.

[2] J. W. Clader, J. Med. Chem. 2004, 47, 1-9.

[3] a) B. Alcaide, P. Almendros, C. Aragoncillo, Chem. Rev. 2007, 107, 4437-4492; b) C. Palomo, M. Oiarbide, Top. Heterocycl. Chem. 2010, 22, 211-259.

[4] a) A. Arrieta, B. Lecea, F. P. Cossío, Top. Heterocycl. Chem. 2010, 22, 313-347; b) R. Tuba, Org. Biomol. Chem. 2013, 11, 5976-5988; c) C. Palomo, J. M. Aizpurua, I. Ganboa, M. Oiarbide, Curr. Med. Chem. 2004, 11, 1837-1872; d) A. Tarui, K. Sato, M. Omote, I. Kumadaki, A. Ando, Adv. Synth. Catal. 2010, 352, 2733-2744.

[5] a) P. D. Mehta, N. P. S. Sengar, A. K. Pathak, Eur. J. Med. Chem. 2010, 45, 5541-5560; b) S. B. Rosenblum, T. Huynh, A. Afonso, H. R. Davis, J. N. Yumibe, J. W. Clader, D. A. Burnett, J. Med. Chem. 1998, 41, 973-980.

[6] a) R. K. Khangarot, K. P. Kaliappan, Eur. J. Org. Chem. 2013, 7664-7677; b) C. R. Pitts, T. Lectka, Chem. Rev. 2014, 114, 7930-7953; c) L. Troisi, C. Granito, E. Pindinelli, Top. Heterocycl. Chem. 2010, 22, 101-209; d) B. Alcaide, P. Almendros, A. Luna, $R S C A d v$. 2014, 4, 1689-1707; e) A. Kamath, I. Ojima, Tetrahedron 2012, 68, 10640-10664.

[7] a) W. Adam, P. Groer, H.-U. Humpf, C. R. Saha-Möller, J. Org. Chem. 2000, 65, 4919-4922; b) A. Basak, S. C. Ghosh, Synlett 2004, 9, 1637-1639; c) X. Wang, F. Meng, Y. Wang, Z. Han, Y. Chen, L. Liu, Z. Wang, K. Ding, Angew. Chem. Int. Ed. 2012, 51, 9276-9282; Angew. Chem. 2012, 124, 9410-9416; d) W. Li, C. Liu, H. Zhang, K. Ye, G. Zhang, W. Zhang, Z. Duan, S. You, A. Lei, Angew. Chem. Int. Ed. 2014, 53, 2443 2446; Angew. Chem. 2014, 126, 2475-2478.

[8] a) B. Ganem, Acc. Chem. Res. 2009, 42, 463-472; b) C. de Graaff, E. Ruijter, R. V. A. Orru, Chem. Soc. Rev. 2012, 41, 3969-4009; c) S. S. van Berkel, B. G. M. Bögels, M. A. Wijdeven, B. Westermann, F. P. J. T. Rutjes, Eur. J. Org. Chem. 2012, 3543-3559; d) L. H. Choudhury, T. Parvin, Tetrahedron 2011, 67, 8213-8228; e) S. Sadjadi, M. M. Heravi, Tetrahedron 2011, 67, 2707-2752.

[9] a) I. Ojima, M. Tzamarioudaki, Z. Li, R. J. Donovan, Chem. Rev. 1996, 96, 635-662; b) N. T. Patil, Y. Yamamoto, Chem. Rev. 2008, 108, 3395-3442; c) H. Clavier, H. Pellissier, $A d v$. Synth. Catal. 2012, 354, 3347-3403.

[10] a) J. D. Sunderhaus, S. F. Martin, Chem. Eur. J. 2009, 15, 1300 1308; b) E. Ruijter, R. Scheffelaar, R. V. A. Orru, Angew. Chem. Int. Ed. 2011, 50, 6234-6246; Angew. Chem. 2011, 123, 6358-6371; c) D. M. D’Souza, T. J. J. Müller, Chem. Soc. Rev. 2007, 36, 1095-1108; d) A. Salcedo, L. Neuville, C. Rondot, P. Retailleau, J. Zhu, Org. Lett. 2008, 10, 857-860; e) R. A. De Silva, S. Santra, P. R. Andreana, Org. Lett. 2008, 10, 45414544; f) L. E. Kaïm, L. Grimaud, X. L. Goff, M. Menes-Arzate, L. D. Miranda, Chem. Commun. 2011, 47, 8145-8147; g) L. Zhang, F. Zhao, M. Zheng, Y. Zhai, H. Liu, Chem. Commun. 2013, 49, 2894-2896.

[11] a) S. Gedey, J. Van der Eycken, F. Fülöp, Org. Lett. 2002, 4, 1967-1969; b) Z. Szakonyi, R. Sillanpää, F. Fülöp, Mol. Diversity 2010, 14, 59-65; c) M. C. Pirrung, K. Das Sarma, J. Am. Chem. Soc. 2004, 126, 444445.

[12] M. C. Pirrung, K. Das Sarma, Synlett 2004, 8, 1425-1427.

[13] X. H. Zeng, H. M. Wang, Y. M. Yan, L. Wu, M. W. Ding, Tetrahedron 2014, 70, 3647-3652.

[14] E. Ghabraie, S. Balalaie, S. Mehrparvar, F. Rominger, J. Org. Chem. 2014, 79, 7926-7934.

[15] a) S. G. Modha, D. D. Vachhani, J. Jacobs, L. Van Meervelt, E. V. Van der Eycken, Chem. Commun. 2012, 48, 6550-6552; b) A. Kumar, Z. Li, S. K. Sharma, V. S. Parmar, E. V. Van der Eycken, Chem. Commun. 2013, 49, 6803-6805; c) S. G. Modha, A. Kumar, D. D. Vachhani, J. Jacobs, S. K. Sharma, V. S. Parmar, L. Van Meervelt, E. V. Van der Eycken, Angew. Chem. Int. Ed. 2012, 51, 9572-9575; Angew. Chem. 2012, 124, 
9710-9713; d) A. Kumar, Z. Li, S. K. Sharma, V. S. Parmar, E. V. Van der Eycken, Org. Lett. 2013, 15, 1874-1877; e) Z. Li, L. Legras, A. Kumar, D. D. Vachhani, S. K. Sharma, V. S. Parmar, E. V. Van der Eycken, Tetrahedron Lett. 2014, 55, 20702074; f) Z. Li, A. Kumar, D. D. Vachhani, S. K. Sharma, V. S. Parmar, E. V. Van der Eycken, Eur. J. Org. Chem. 2014, 2084 2091; g) Z. Li, A. Kumar, S. K. Sharma, V. S. Parmar, E. V. Van der Eycken, Tetrahedron 2015, 71, 3333-3342.

[16] a) A. Dömling, I. Ugi, Angew. Chem. Int. Ed. 2000, 39, 31683210; Angew. Chem. 2000, 112, 3300-3344; b) A. Dömling, Chem. Rev. 2006, 106, 17-89.

[17] a) B. K. Banik, A. Ghatak, F. F. Becker, J. Chem. Soc. Perkin Trans. 1 2000, 2179-2181; b) K. Takahashi, M. Midori, K. Kawano, J. Ishihara, S. Hatakeyama, Angew. Chem. Int. Ed. 2008, 47, 6244-6246; Angew. Chem, 120, 6340-6342; c) S. Hatakeyama, Pure Appl. Chem. 2009, 81, 217-226; d) F. Urabe, S. Nagashima, K. Takahashi, J. Ishihara, S. Hatakeyama, J. Org. Chem. 2013, 78, 3847-3857; e) K. Endo, T. Hatakeyama, M. Nakamura, E. Nakamura, J. Am. Chem. Soc. 2007, 129, 5264-5271; f) R. Takita, Y. Fukuta, R. Tsuji, T. Ohshima, M. Shibasaki, Org. Lett. 2005, 7, 1363-1366; g) G. K. Friestad, C. S. Korapala, H. Ding, J. Org. Chem. 2006, 71, 281-289; h) Z. Shen, S. Wang, Y. Chok, Y. Xu, T. Loh, Chem. Rev. 2013, 113, 271-401; i) D. Prajapati, R. Sarma, D. Bhuyan, W. Hu, Synlett 2011, 5, 627-630; j) C. C. Malakar, B. U. W. Maes, K. A. Tehrani, Adv. Synth. Catal. 2012, 354, 3461-3467; k) Y. Itoh, H. Tsuji, K. Yamagata, K. Endo, I. Tanaka, M. Nakamura, E. Nakamura, J. Am. Chem. Soc. 2008, 130, 17161-
17167; 1) M. Nakamura, K. Endo, E. Nakamura, J. Am. Chem. Soc. 2003, 125, 13002-13003; m) T. Fujimoto, K. Endo, H. Tsuji, M. Nakamura, E. Nakamura, J. Am. Chem. Soc. 2008, 130, 4492-4496; n) W. Hess, J. W. Burton, Adv. Synth. Catal. 2011, 353, 2966-2970; o) S. Yamazaki, Chem. Eur. J. 2008, 14, 6026-6036; p) S. Shaw, J. D. White, J. Am. Chem. Soc. 2014, 136, 13578-13581; q) B. Montaignac, M. R. Vitale, V. Michelet, V. Ratovelomanana-Vidal, Org. Lett. 2010, 12, 2582-2585.

[18] M. J. Frisch, G. W. Trucks, H. B. Schlegel, G. E. Scuseria, M. A. Robb, J. R. Cheeseman, G. Scalmani, V. Barone, B. Mennucci, G. A. Petersson, H. Nakatsuji, M. Caricato, X. Li, H. P. Hratchian, A. F. Izmaylov, J. Bloino, G. Zheng, J. L. Sonnenberg, M. Hada, M. Ehara, K. Toyota, R. Fukuda, J. Hasegawa, M. Ishida, T. Nakajima, Y. Honda, O. Kitao, H. Nakai, T. Vreven, J. A. Montgomery Jr., J. E. Peralta, F. Ogliaro, M. Bearpark, J. J. Heyd, E. Brothers, K. N. Kudin, V. N. Staroverov, R. Kobayashi, J. Normand, K. Raghavachari, A. Rendell, J. C. Burant, S. S. Iyengar, J. Tomasi, M. Cossi, N. Rega, J. M. Millam, M. Klene, J. E. Knox, J. B. Cross, V. Bakken, C. Adamo, J. Jaramillo, R. Gomperts, R. E. Stratmann, O. Yazyev, A. J. Austin, R. Cammi, C. Pomelli, J. W. Ochterski, R. L. Martin, K. Morokuma, V. G. Zakrzewski, G. A. Voth, P. Salvador, J. J. Dannenberg, S. Dapprich, A. D. Daniels, O. Farkas, J. B. Foresman, J. V. Ortiz, J. Cioslowski, D. J. Fox, Gaussian 09, revision B, Gaussian, Inc., Wallingford, CT, 2009.

Received: February 25, 2015 Published Online: 

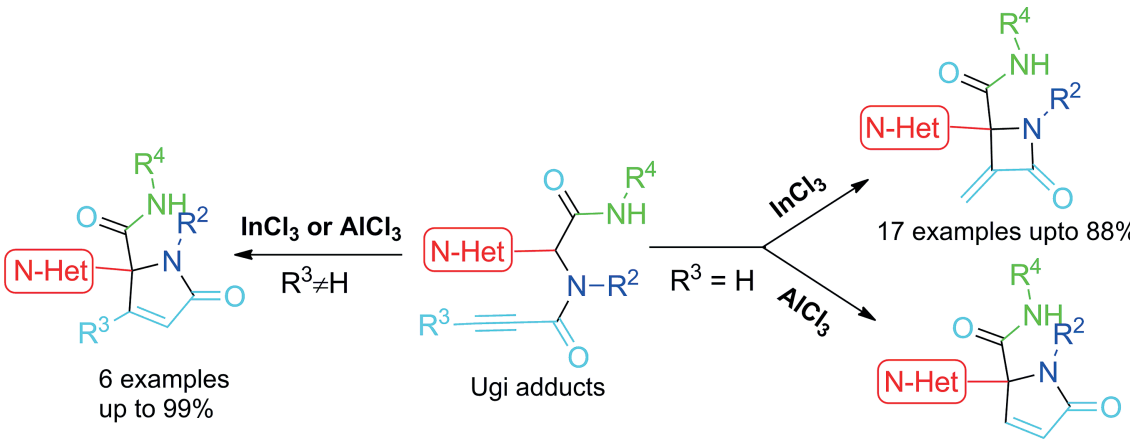

7 examples up to $75 \%$

A regioselective approach for the synthesis of heterocyclic fused $\alpha$-methylene $\beta$-lactams and $\alpha, \beta$-unsaturated $\gamma$-lactams by em- ploying a Ugi reaction followed by $\mathrm{In}^{\mathrm{III}}$ - or $\mathrm{Al}^{\mathrm{III}}$-catalyzed intramolecular nucleophilic addition is reported.
Z. Li, U. K. Sharma, Z. Liu, N. Sharma, J. N. Harvey,

E. V. Van der Eycken* 1-7

Diversity-Oriented Synthesis of $\beta$-Lactams and $\gamma$-Lactams by Post-Ugi Nucleophilic Cyclization: Lewis Acids as Regioselective Switch

Keywords: Multicomponent reactions / Nucleophilic cyclization / Regioselectivity / Lewis acids / Lactams 